\title{
Characteristics and origin of deformation structures within lignite seams - a case study from Polish opencast mines
}

\author{
Marek WIDERA ${ }^{1, *}$ \\ 1 Adam Mickiewicz University, Institute of Geology, Maków Polnych 16, 61-606 Poznań, Poland
}

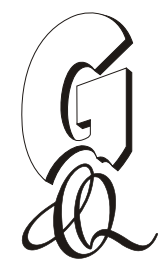

Widera, M., 2016. Characteristics and origin of deformation structures within lignite seams - a case study from Polish opencast mines. Geological Quarterly, 60 (1): 181-191, doi: 10.7306/gq.1268

\begin{abstract}
The present paper discusses the genesis of some deformation structures within Miocene lignite seams in Poland. These meso- to macro-scale deformation structures are the best developed in areas where the thickest lignite seams are exploited, that is, in the Bełchatów, Turów and Lubstów lignite opencast mines. They show a wide variety of structures such as high-angle inclined strata, normal and reverse faults and folds, fractures and clastic dikes. These deformation structures were not analysed in terms of the structural development of the lignite-bearing areas, but rather in the context of their origin. The high-angle inclination of clastic sedimentary strata clearly formed mainly as a result of vertical tectonic movements in the sub-Cenozoic basement, their currently measured dip angle being significantly higher than their natural angle of repose. All the observed normal and reverse faults cutting the Miocene strata are a clear example of syn- and/or post-depositional tectonics. The normal faults clearly indicate tensional tectonics while the reverse faults reflect compressional tectonics. In turn, the majority of folds occurring within the lignite seams are a result of peat/lignite compaction. However, one of the folds studied is predominantly the result of vertical displacements in the sub-Cenozoic basement. The en echelon fracture pattern may additionally indicate the horizontal component of these displacements. Finally, the most spectacular and debatable structures are clastic dikes. In this study the genesis of some of them is linked with the evolution of the graben's marginal fault.
\end{abstract}

Key words: high-angle inclined strata, faults, folds, fractures, clastic dikes, lignite seams.

\section{INTRODUCTION}

The literature on the geology of lignite-bearing areas provides much information on both tectonic and non-tectonic deformation structures shown in geological cross-sections or digital models. However, the patterns shown in this way often do not correspond with field observations. On the other hand, the deformation structures within the lignite seams are only well-documented, for example via photographs and/or drawings, in a few scientific studies. The most evident deformation structures, mainly different types of faults and folds, come from the lignite opencast pits operating in such countries as the Czech Republic (e.g., Rajchl et al., 2009), Greece (e.g., Diamantopoulos et al., 2004; Diamantopoulos, 2006), Poland (e.g., Widera, 1998, 2007, 2013, 2014; Gotowała and Hałuszczak, 2002; Widera and Hałuszczak, 2011) and Turkey (e.g., Yilmaz et al., 2006). This paper provides the first description and interpretation of other types of deformation structures within Polish lignite seams.

The Polish lignite mines provide an excellent opportunity for such observations. Three lignite-bearing areas have been selected in order to illustrate the best-developed and most inter-

\section{*E-mail: widera@amu.edu.pl}

Received: July 25, 2015; accepted: October 25, 2015; first published online: December 17, 2015 esting deformation structures. These are the Bełchatów, Turów and Lubstów lignite deposits where lignite seams were or are being exploited (Fig. 1). These seams also belong among the thickest not just in Poland but also in Europe and around the world. The continuous thickness of the lignite seams studied varies from 35 to $70 \mathrm{~m}$ in the Turów lignite deposit to almost $90 \mathrm{~m}$ in the Lubstów lignite deposit, and $>250 \mathrm{~m}$ in the Bełchatów lignite deposit (Piwocki, 1992; Widera, 1998, 2013; Kasiński, 2000).

The current study aims to provide the clearest descriptions and interpretations of the deformation structures from these selected lignite-bearing areas in Poland. Most of the deformation structures are of tectonic origin. Therefore, the deepest Cenozoic depressions have been taken into account, where lignite seams are unusually thick and were tectonically subjected to the greatest vertical movements. A secondary objective of this study is to clarify the genesis of the deformational structures. These are of various origins and therefore need thorough discussion.

\section{GEOLOGICAL SETTING}

The lignite-bearing areas investigated belong to the North-West European Paleogene-Neogene Basin (Vinken, 1988). In the eastern part of this basin, i.e. in Poland, the lithostratigraphy is very rarely constrained by microfauna and/or microflora (Piwocki and Ziembińska-Tworzydło, 1997). Thus, especially in the case of the Neogene, lignite seams play an important stratigraphic role in facilitating correlation with south- 

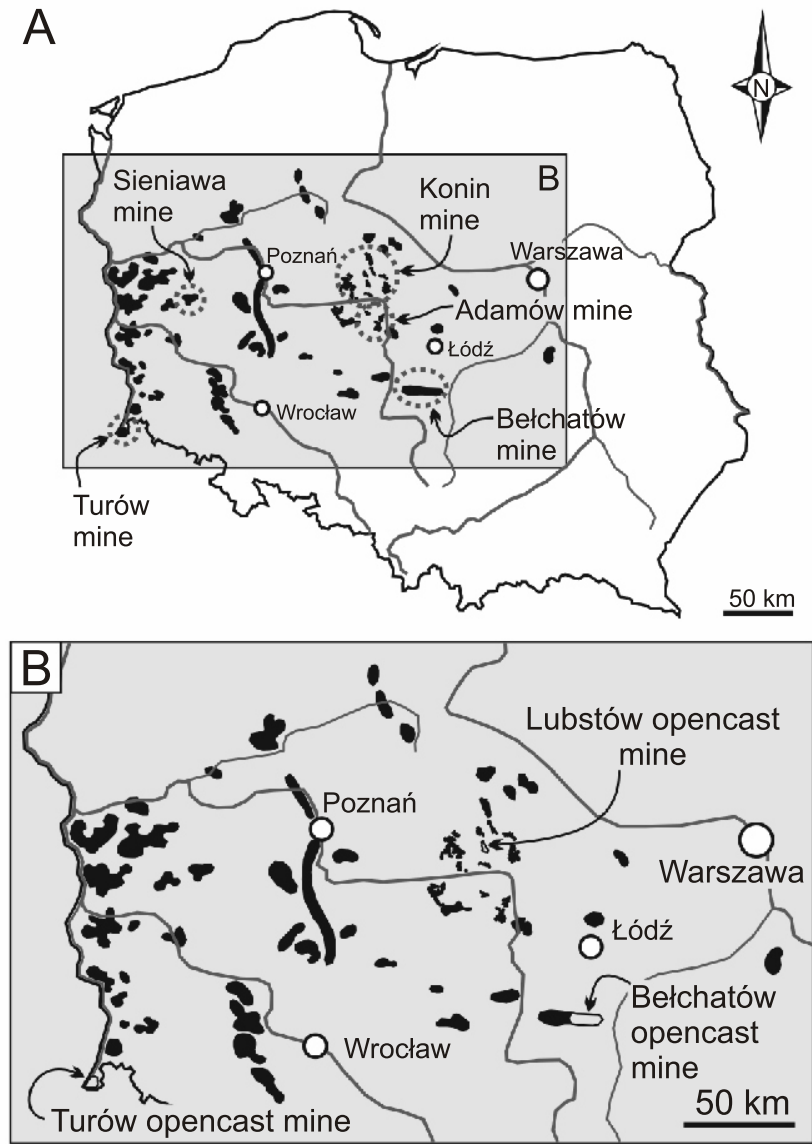

Fig. 1. Location map (after Ciuk and Piwocki, 1990; Piwocki, 1992; Piwocki and Kasiński, 1994; modified)

A - main lignite deposits in Poland with areas of the operating lignite mines indicated by dotted circles; $\mathbf{B}$ - location of the lignite opencast mines studied

eastern Germany where the associated mineral deposits are more precisely dated by microfauna and dinocysts (Standke et al., 1993; Grimm et al., 2002).

Currently, three lignite seams are being exploited in Poland. However, the two oldest seams in the lignite mines studied have industrial value. These seams belong stratigraphically to the third Ścinawa lignite seam, ŚS-3, the second Lusatian lignite seam, LLS-2, and the first Mid-Polish lignite seam, MPLS-1 (Fig. 2). As stated above, they can be easily correlated with the third, second, and first Lusatian lignite seams in south-eastern Germany, respectively (Piwocki and Ziembińska-Tworzydło, 1997). All of them are of Miocene age (Fig. 2). The associated lignite opencast mines are located in the following tectonic units: the Kleszczów Graben, the Zittau Basin and the Lubstów Graben.

\section{THE KLESZCZÓW GRABEN}

The Bełchatów lignite opencast mine is located in the

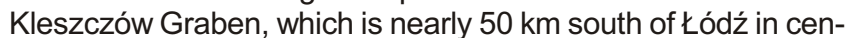
tral Poland (Fig. 1A). It is a tectonic depression $>500 \mathrm{~m}$ deep whose bottom lies below $400 \mathrm{~m}$ b.s.l. and its margins are elevated at $>100 \mathrm{~m}$ a.s.l. (Gotowała and Hałuszczak, 2002). Thus, the Kleszczów Graben is the deepest Cenozoic graben with the thickest (>250 m) lignite seam in Poland (Piwocki, 1992).

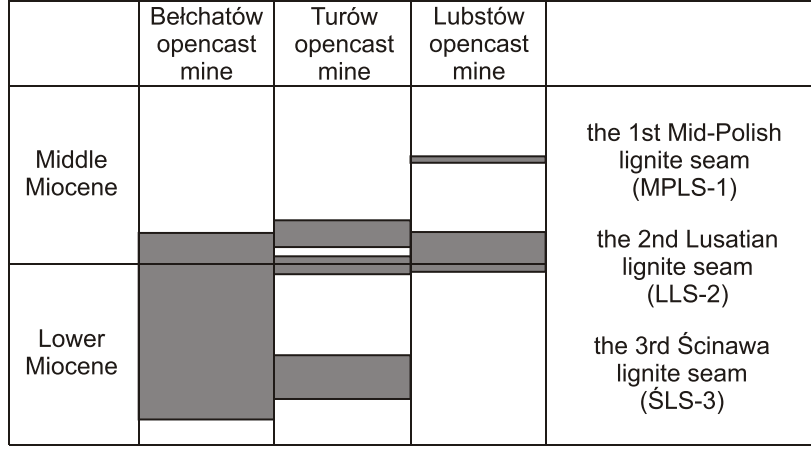

Fig. 2. Generalized stratigraphic position of the lignite seams mentioned in the text

(after Piwocki and Ziembińska-Tworzydło, 1997; modified)

The Kleszczów Graben extends over a distance of $80 \mathrm{~km}$, is $\mathrm{E}-\mathrm{W}$-trending and is 2 to $3 \mathrm{~km}$ wide. However, its central portion, which is about $25 \mathrm{~km}$ long, contains the richest lignite seam (Fig. 3A). Structurally, this graben consists of NW-SE-, NE-SW-, WSW-ENE-, and WNW-ENE-trending faults that are inherited from older discontinuities (Gotowała and Hałuszczak, 2002). The southern and northern master faults are the most clearly visible ones in the field. These bounding faults of the graben are characterized by a throw of more than 200 to 300 m (Widera and Hałuszczak, 2011). The graben is also divided by the salt dome into two segments. The observations presented here were largely made in the eastern segment of the Kleszczów Graben, i.e. in the Bełchatów opencast mine (Fig. 1B).

Tectonic evolution of the Kleszczów Graben during the Cenozoic commenced initially in the Early Oligocene (Czarnecki et al., 1992). However, the sedimentation of the lignite-bearing association started around the Oligocene-Miocene boundary as reflected by the presence of Early Miocene deposits at the base of the succession. Then, the sub-lignite clastic strata and the main lignite seam, comprising together the third Ścinawa lignite seam (ŚLS-3), and the second Lusatian lignite seam (LLS-2), were deposited (Figs. 2 and 3A). After a short period of uplift, graben subsidence continued between the Late Miocene and the mid Quaternary. At this time, the youngest Neogene clastic strata and the oldest Pleistocene glaciogenic formations were deposited. Finally, the recent tectonic activity of the Kleszczów Graben started during the mid-Pleistocene (260 ka) and has continued up to the present day. This recent activity is expressed by a great number of earthquakes caused by mining activity and/or salt dome uplift (Gotowała and Hałuszczak, 2002; Hałuszczak, 2004).

\section{THE ZITTAU BASIN}

The Turów lignite opencast mine covers only the Polish part of the Zittau Basin in the most southwestern region of Poland (Fig. 1). It is considered as the northeastern segment of the Eger (Ohře) Graben in the Bohemian Massif (Malkovsky, 1987; Kasiński, 2000; Špičáková et al., 2000; Rajchl et al., 2009; Kasiński et al., 2015). On the other hand, the Eger (Ohře) Graben is an integral part of the European Cenozoic Rift System - ECRiS (Ziegler and Dèzes, 2007).

The majority of the Zittau Basin lies in Poland, and less than half of it is located in Germany and the Czech Republic. This tectonosedimentary basin has an irregular shape, which is generally E-W-trending, around $20 \mathrm{~km}$ long, $15 \mathrm{~km}$ wide, and more 


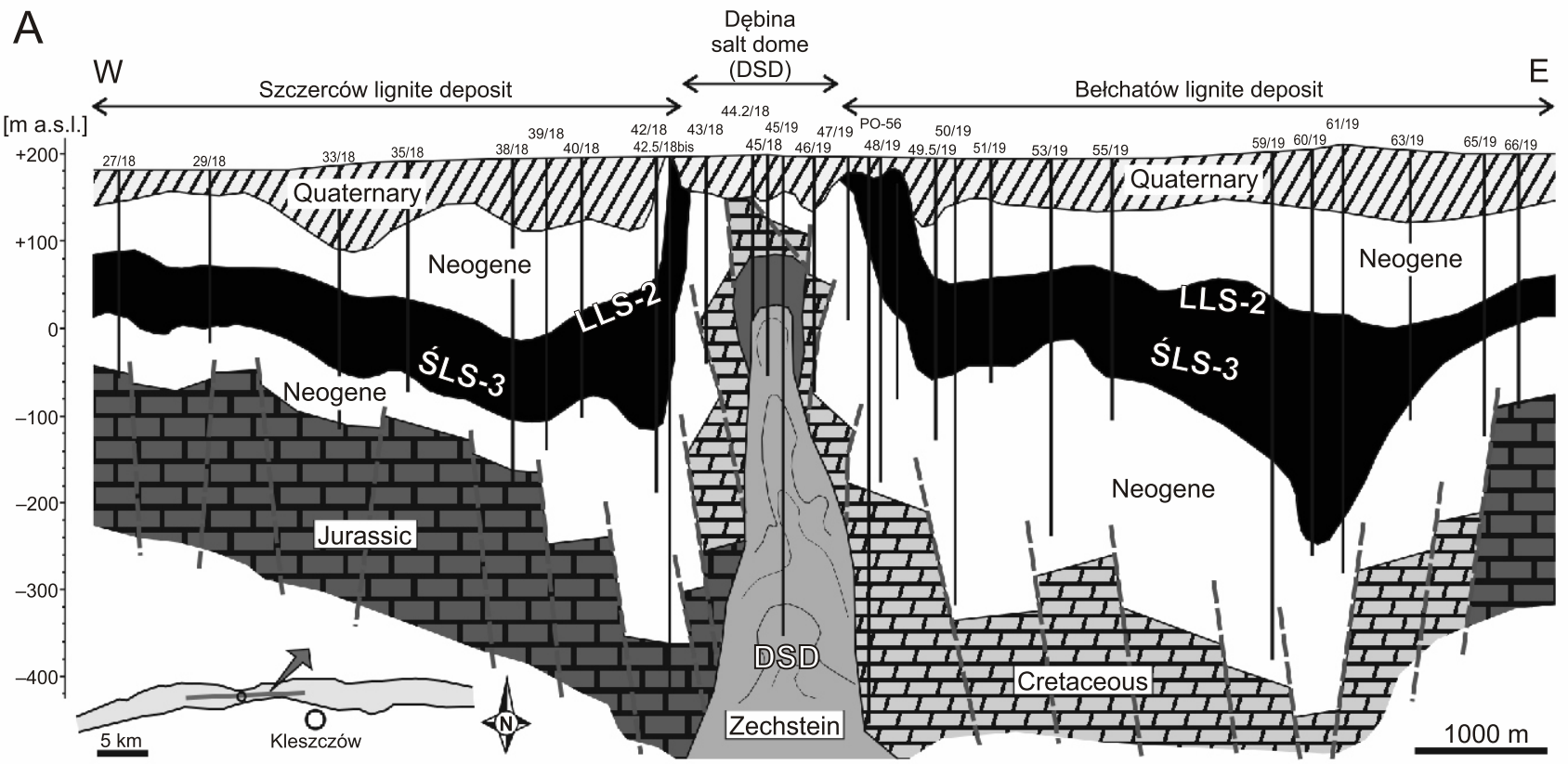

B

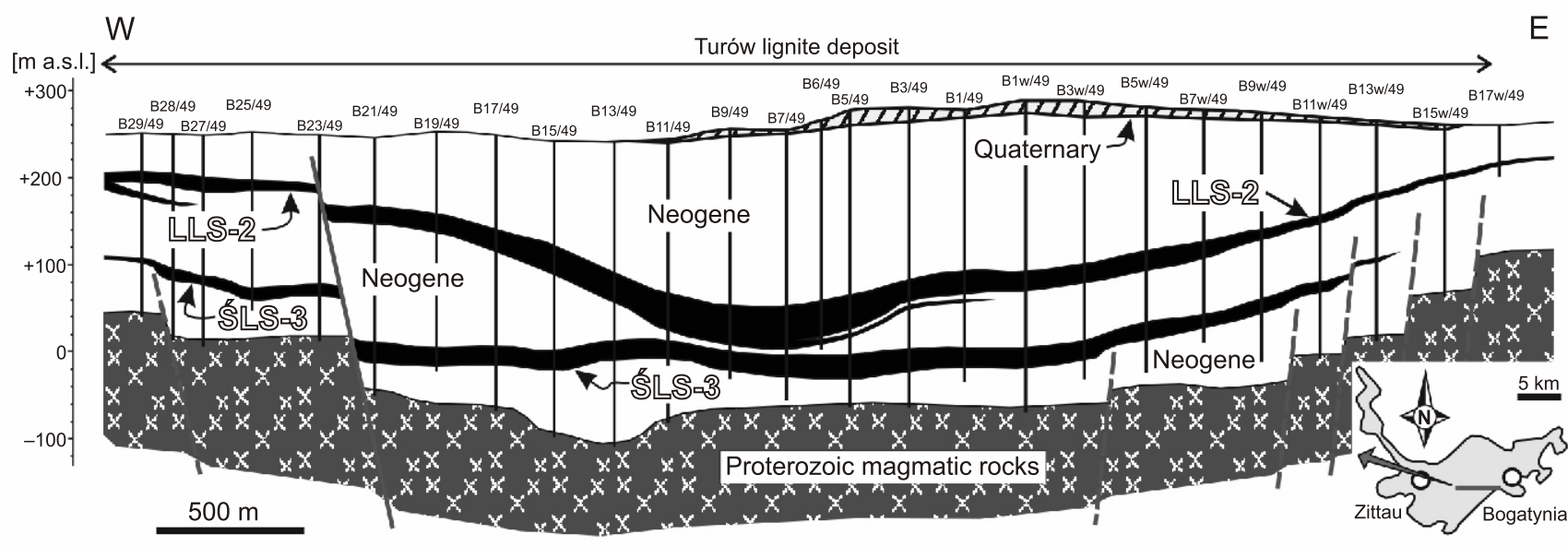

C

NW

SE|WNW

ESE

Lubsów lignite deposit

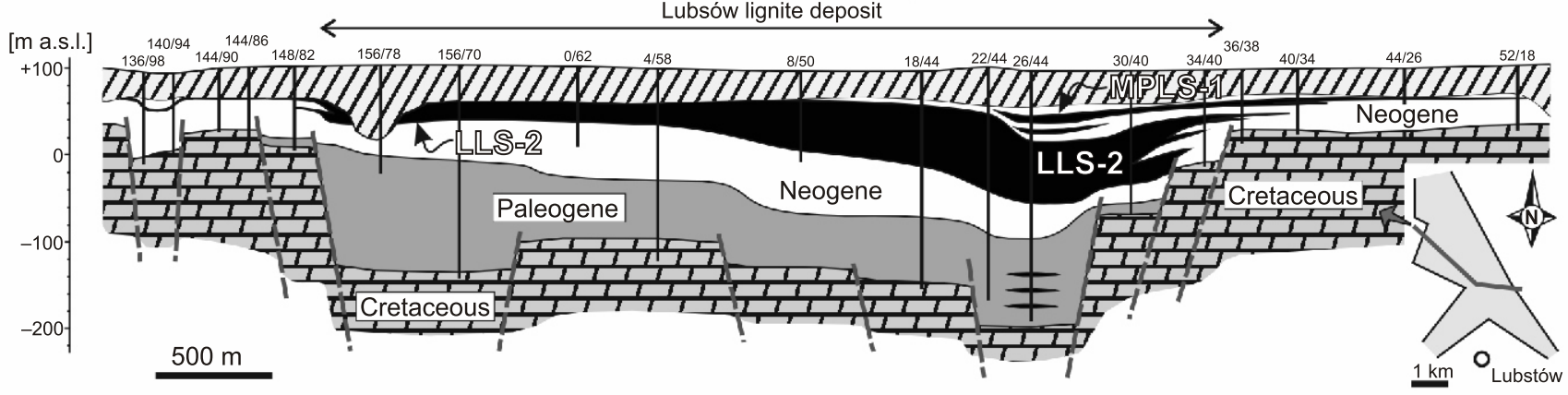

Fig. 3. Geological sections across the study areas showing the influence of tectonic activity on lignite seam architecture

A - cross-section through the Bełchatów Graben (after Gotowała and Hałuszczak, 2002; and mine data); B - cross-section through the Zittau Basin (based on mine data); C - cross-section through the Lubstów Graben (after Widera, 1998); note the stratigraphic and palaeotopographic diversity in the sub-Cenozoic basement where the presumed faults are marked by dashed lines and the certain fault is indicated by the solid line; $27 / 18$ - borehole number; other explanations as in Figure 2 
than 200 to $400 \mathrm{~m}$ deep (Fig. 3B). Its crystalline basement lies at between $<80 \mathrm{~m}$ b.s.l. and $>300 \mathrm{~m}$ a.s.l. (Kasiński, 2000). Moreover, it is strongly tectonized with two older NW-SE-trending, NE-SW-trending, and younger W-E-trending fault directions (Kasiński, 2000).

The initial subsidence of the Zittau Basin took place not later than in the Late Oligocene as recently documented by Kasińsk et al. (2015). Then, pronounced Cenozoic development of the Zittau Basin took place around the Oligocene-Miocene boundary. Initial deposition was of clastic sediments and the third Ścinawa lignite seam, ŚLS-3 (35 m) of Early Miocene age (Piwocki and Ziembińska-Tworzydło, 1997; Kasiński, 2000). In the Middle Miocene there accumulated, inter alia, the second Lusatian lignite seam, LLS-2 $(70 \mathrm{~m})$, which is split into two benches (Fig. 2; Kasiński, 2000). The upper lignite bench is better developed in the northern part of the basin, whereas the lower bench covers almost the entire area of the Zittau Basin. Above the Neogene strata there are relatively thin relicts of the Quaternary cover (Fig. 3B).

\section{THE LUBSTÓW GRABEN}

The Lubstów lignite opencast mine covers the area of the Lubstów Graben, which is located between Poznań and Warsaw (Fig. 1A). It is a tectonic depression more than 220 to $240 \mathrm{~m}$ deep. The Mesozoic substratum lies at a height of 40 to $60 \mathrm{~m}$ a.s.l. in the surrounding area and is $<180 \mathrm{~m}$ b.s.l. in the deepest part of the graben (Widera, 1998, 2007). This Cenozoic tectonic structure is, therefore, second in terms of the depth and thickness of the lignite seam $(90 \mathrm{~m})$ in central Poland.

The Lubstów Graben extends over a distance of $6 \mathrm{~km}$, broadly NNW-SSE-trending and 1 to $3 \mathrm{~km}$ wide (Fig. 3C). This graben consists of N-S- and mainly NW-SE- and NE-SW-trending faults. The last two fault sets are inherited from pre-Cenozoic discontinuities. The Lubstów Graben is situated above a salt structure, which only partially pierces the Mesozoic cover (Widera, 1998).

This graben is the oldest tectonically generated structure of all those discussed in this contribution, and Cenozoic development had already begun in the Paleogene, i.e. around the Eocene-Oligocene boundary. This is shown by the presence of thick Early Oligocene deposits in the deepest parts of the
Lubstów Graben (Widera and Kita, 2007). During the Late Oligocene the entirety of central Poland, including the Lubstów and Bełchatów territories, was subjected to regional uplift (Jarosiński et al., 2009). Following this period, from the Early to Middle Miocene, clastic and organic sediments were deposited. In conditions of relatively steady and long-lasting subsidence the second Lusatian lignite seam, LLS-2, accumulated (Figs. 2 and $3 \mathrm{C}$ ). Between the formation of this lignite seam and deposition of the Pleistocene glaciogenic deposits the deepest parts of the Lubstów Graben were significantly uplifted (Widera, 2007, 2011).

\section{DATA AND METHODS}

The areas under study have been intensively explored because of their lignite-rich content. The number of borehole profiles where the lignite seams have been drilled is $>3,000$ in the Bełchatów opencast mine, $>2,300$ in the Turów opencast mine, and >350 in the Lubstów lignite deposits (Widera, 1998, 2007; Kasiński, 2000; Gotowała and Hałuszczak, 2002).

After preliminary examination of these borehole profiles only a small number of them were selected and included in this contribution. Thus, three generalized cross-sections were prepared on the basis of sufficient information from 73 borehole profiles: 28 from the Bełchatów lignite deposit, 26 from the Turów lignite deposit, and 19 from the Lubstów lignite deposit (Fig. 3). The depth of these boreholes ranged from $<100 \mathrm{~m}$ in the territory of Lubstów to $>500 \mathrm{~m}$ in the area of Bełchatów. They always pierced the lignite seam/seams and locally reached the sub-Cenozoic basement. Two of them are characterized by extraordinary thickness of the lignite seam, namely borehole no. 60/19 in the Bełchatów lignite deposit and borehole no. 22/44 in the Lubstów lignite deposit. The continuous lignite thickness in SLS-3 and LLS-2 is $250.4 \mathrm{~m}$, and that in LLS-2 is $86.2 \mathrm{~m}$, respectively (Fig. 3A, C).

Field observations played the most important role in this research. A great number of tectonic deformation structures was first identified and measured in the lignite opencasts, and then photographically documented (e.g. Figs. 4-7). In the interpretation, the overall tectonic context, lignite compaction and local non-tectonic genesis of the deformation structures have been taken into account.
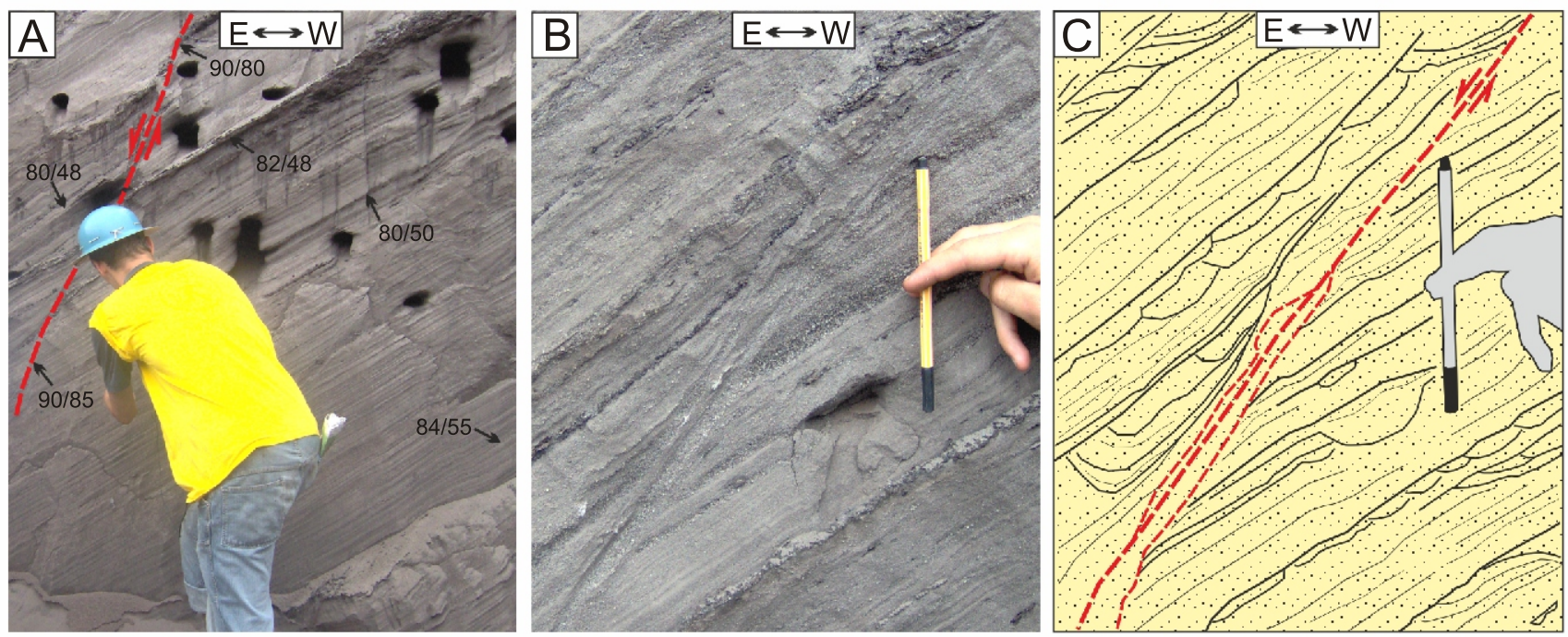

Fig. 4. High-angle inclined and faulted sands

A - general view of the high-angle inclined and faulted sands underlying the 2nd Lusatian lignite seam, LLS-2, in the Lubstów opencast mine; the fault plane is indicated by the dashed line and bedding is described as dip direction/dip angle; B - enlarged details showing the fault zone; $\mathrm{C}$ - interpretative sketch of the photograph shown in Figure 4B; note the anastomosing pattern of the fault zone and drag folds adjacent to the fault zone; arrow - indicates the place where bedding and fault parameters (dip direction/dip angle) were measured 

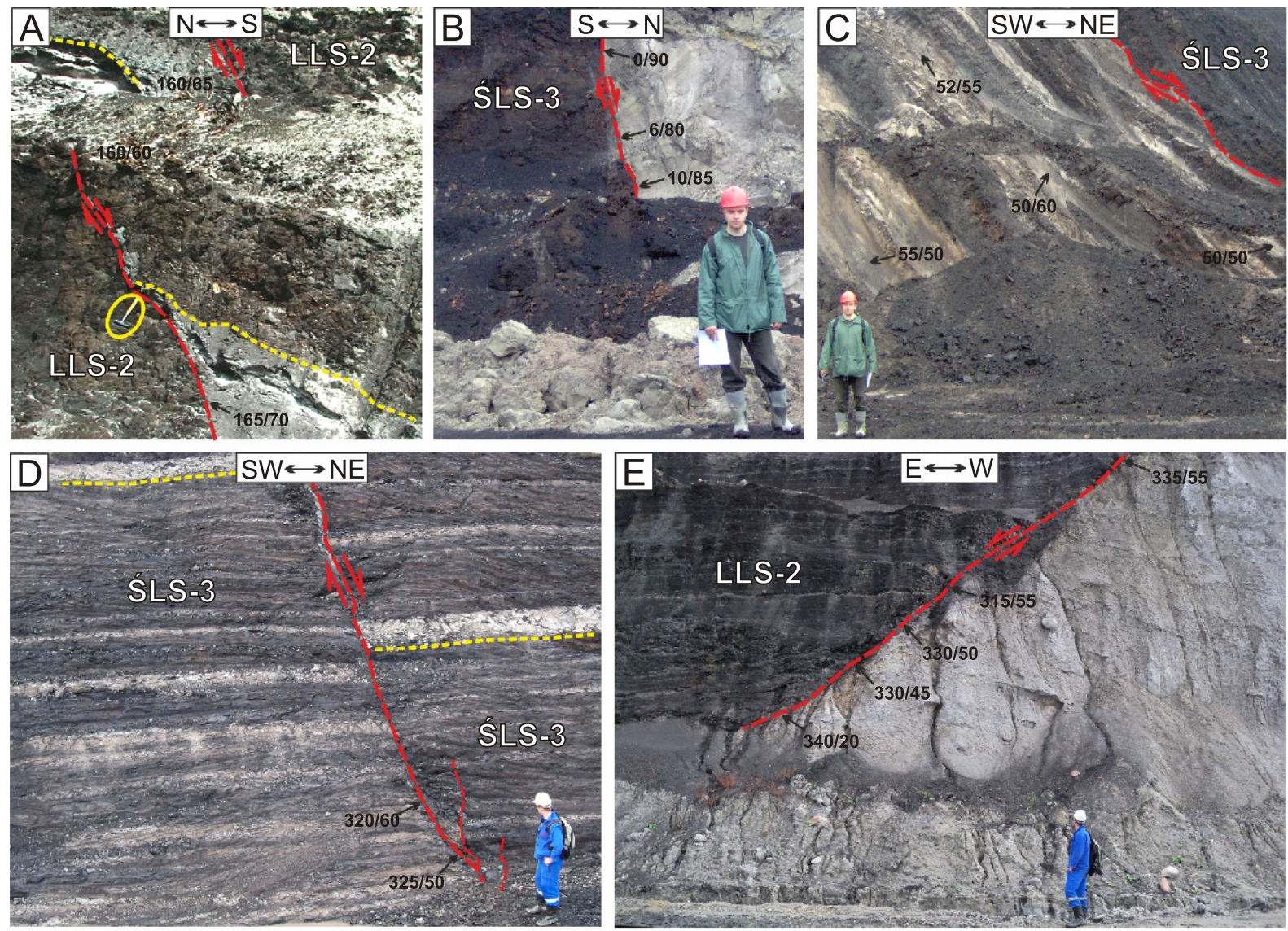

Fig. 5. Macro-scale normal faults occurring within lignite seams and associated deposits

A - normal fault cutting LLS-2 and silty-sand intercalation in the Lubstów opencast mine; note the fault throw is about $2 \mathrm{~m}$; $\mathbf{B}$ - normal fault between ŚLS-3 and clayey-sand dike in the Bełchatów opencast mine; C - fault plane developed on the boundary between ŚLS-3 and the underlying sands, and above the NE slope of the Dębina Salt Dome (DSD) in the Bełchatów opencast mine; D - clearly visible normal fault within layered clays and lignites belonging to SLS-3 in the Turów opencast mine; note that matching layers across the fault surface (clay lighter layers, lignite - darker layers) indicate a fault throw of about $2.5 \mathrm{~m}$, and the presence of low-angle Riedel shears in the lower right corner of the photograph; $\mathbf{E}$ - normal fault between LLS-2 and underlying clastic deposits in the Turów opencast mine; other explanations as in Figure 4

\section{RESULTS}

The Polish lignite deposits, including the thickest lignite seams, are strongly deformed by both external processes such as erosion and glaciotectonics and internal geological processes such as tectonics and compaction (Hager et al., 1981; Widera, 2013). The effects of tectonic processes are the major focus in this study; however, given that some compactionally-induced structures may have the same morphology as some tectonically generated structures, evidence of tectonic activity seen on the cross-sections is given prior to description of structures found in the lignite opencasts.

\section{CROSS-SECTIONS}

The first cross-section covers only the deepest part of the Kleszczów Graben, where the Szczerców and Bełchatów lignite deposits are present (Fig. 3A). The sub-Cenozoic basement is composed of Jurassic and Cretaceous rocks, which are evidently faulted and create the relatively deep graben-like structure. Although this cross-section extends along the axial zone of the graben, some of these faults are also visible in the Bełchatów opencast mine. The main lignite seam (ŚLS-3 and LLS-2) is prominent position among the Neogene strata. It has an average thickness of about $100 \mathrm{~m}$ in the part of the cross-section described, in borehole no. 60/19 reaching $250.4 \mathrm{~m}$, as noted above (Piwocki, 1992; Widera, 2013). A characteristic feature is that the bottom of the lignite seam lies at a lower height in areas where the Mesozoic top forms depressions, e.g. in the vicinity of boreholes no. 59/19, 60/19 and $61 / 19$ (Fig. 3A). Conversely, in areas where the Mesozoic top is higher the bottom of the lignite seam is also elevated. The similar shape of these palaeosurfaces may be further evidence of Cenozoic tectonics in the Bełchatów territory. However, the structure most typical of the Bełchatów mine is the salt structure termed the Dębina Salt Dome (DSD). These salts relate to the Zechstein Sea, but the salt structure took its final shape during the Cenozoic (Gotowała and Hałuszczak, 2002; Kasiński et al., 2009). It is highly elevated and in some cases it lies higher than the roof of the main lignite seam, SLS-3 and LLS-2. In fact, the lignite deposits are divided by the DSD into the Szczerców and Bełchatów lignite deposits. The syn- and/or post-depositional uplift of this salt structure is indicated by the steep inclination of 

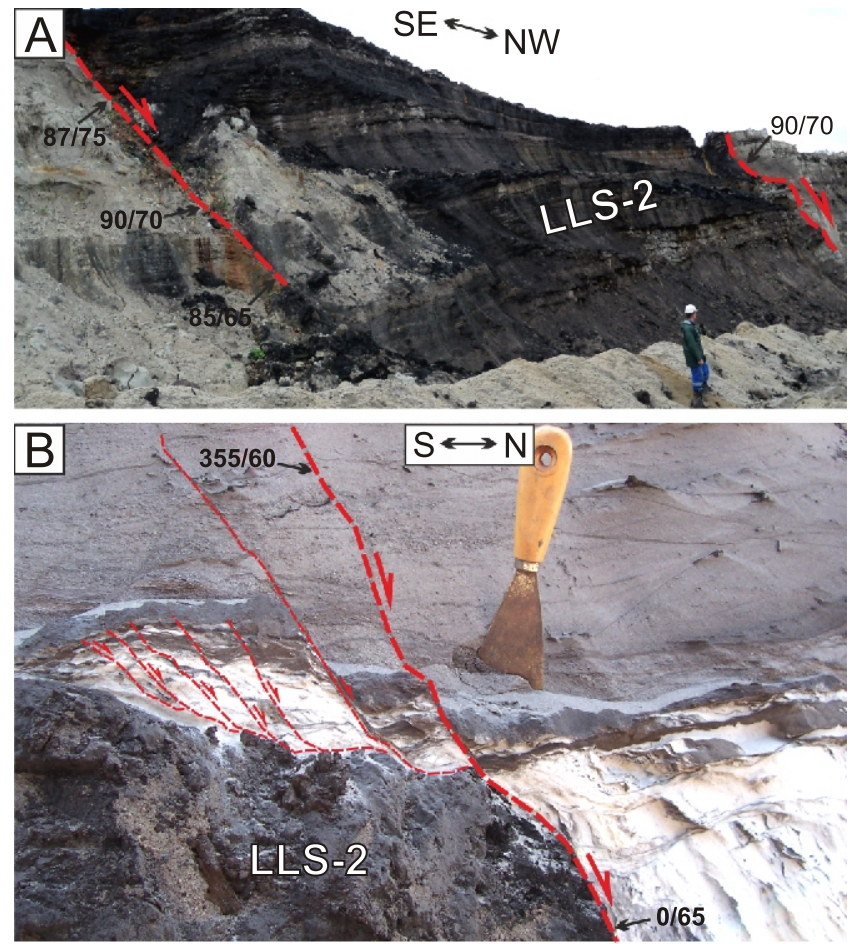

Fig. 6. Step faults of normal-dip displacement developed at various scales

A - macro-scale step faults in the Turów opencast mine; note that LLS-2 is bounded by two normal faults and located between clastic deposits; B - meso-scale step faults in the Lubstów opencast mine; note a number of secondary step faults on the footwall of the primary fault; other explanations as in Figure 4

the lignite layers. It is best expressed in the area adjacent to the DSD, where both the bottom and roof of SLS-3 and LLS-2 are inclined at an angle exceeding $85^{\circ}$ (Fig. 3A).

The cross-section through the Turów lignite deposit does not show very complex tectonics as in the Zittau Basin (Fig. 3B). Only Proterozoic volcanic rocks are present in the sub-Cenozoic basement, whereas in other parts of this basin Cenozoic volcanic rocks are also documented. The Neogene consists, inter alia, of two lignite seams, i.e. ŚLS-3 and LLS-2 (Kasiński, 2000). However, both the sub-Cenozoic basement and lignite seams are evidently faulted. Most of these dislocations were determined on the basis of borehole data. An exception is the fault between boreholes no. B23/49 and B21/49, which was also documented in the field. Its throw in the sub-Cenozoic basement is up to $70 \mathrm{~m}$ and exceeds $30 \mathrm{~m}$ at the top of LLS-2 (Fig. 3B).

The cross-section shown through the Lubstów lignite deposit was placed so as to show the rather complicated geological structure of the Lubstów Graben (Fig. 3C). The sub-Cenozoic basement is composed of Cretaceous rocks, which are evidently faulted. It gives the graben a horst-like structure in the vicinity of borehole no. $4 / 58$. The axial portion of the graben is covered by the Paleogene, i.e. Early Oligocene deposits $>130 \mathrm{~m}$ thick (Widera and Kita, 2007). By analysing the morphology of the Paleogene top it can be easily seen that some of the faults were also tectonically active at a later time. The phenomenon is best expressed by the similar shape of the Mesozoic and Paleogene top surfaces between boreholes no. 4/58, $18 / 44$ and 22/44. Moreover, further evidence of Cenozoic tectonics in the Lubstów Graben area is shown by the bottom of the Lusatian lignite seam (LLS-2) which lies at the lower height
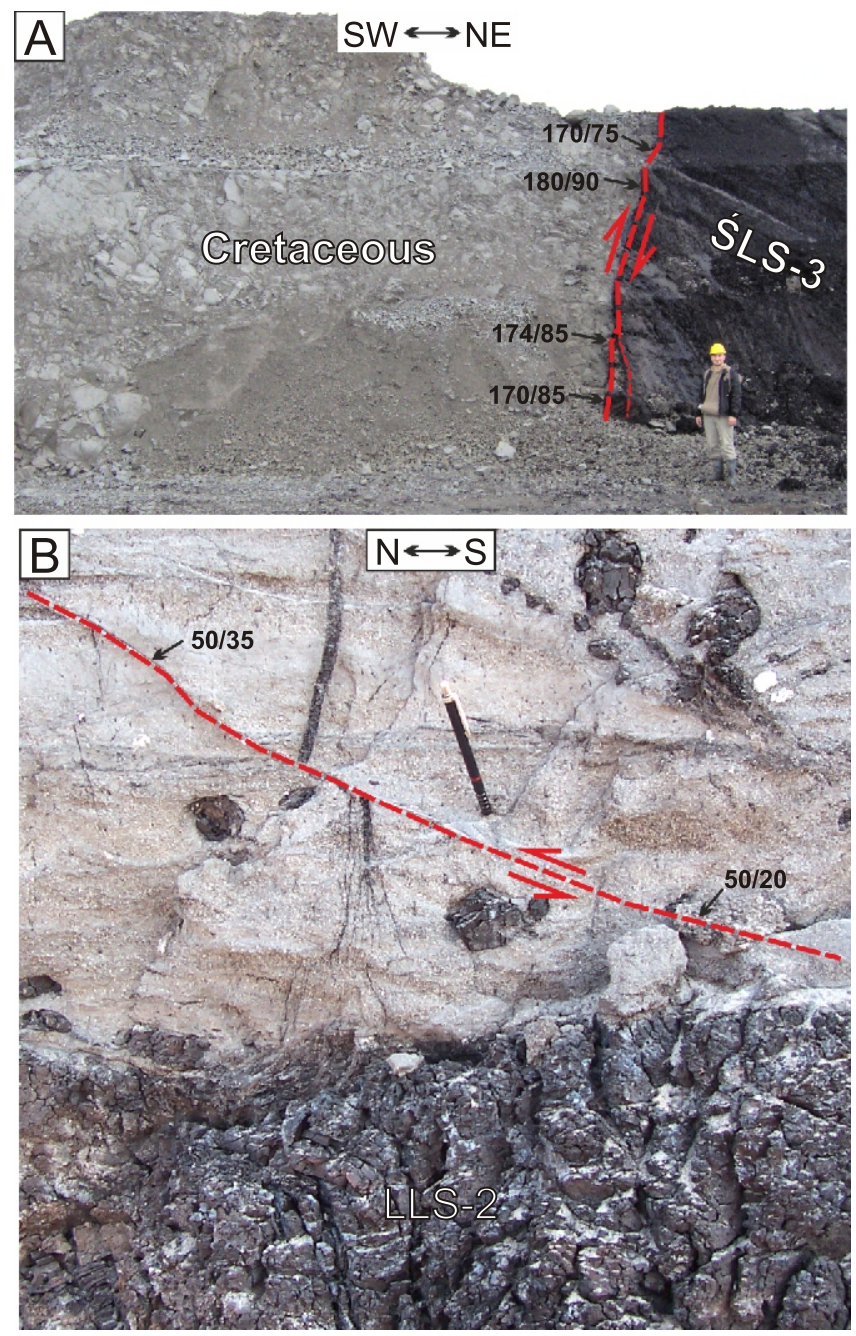

Fig. 7. Reverse faults developed at a various scale

A - macro-scale reverse faulting boundary between the Cretaceous basement and ŚLS-3 in the Bełchatów opencast mine; note the very high-angle to vertical dip of the fault surface; $\mathbf{B}$ - meso-scale reverse fault (thrust fault) developed within sandy intercalation of LLS-2 in the Lubstów opencast mine; note the displacement of plant roots; other explanations as in Figure 4

in territory where the Mesozoic top also forms the deepest depression, e.g. in the vicinity of boreholes no. 22/44 and 26/44 (Fig. 3C). As noted above, this part of the Lubstów Graben was tectonically uplifted by at least $130 \mathrm{~m}$ after deposition of the main Lusatian lignite seam, LLS-2. This is shown, inter alia, by the presence of reverse faults, which have been documented in the field (Widera, 2007, 2011).

\section{FIELD OBSERVATIONS}

High-angle inclined strata. The first group of tectonic deformations are developed within fine-grained siliciclastic deposits underlying the main lignite seam (LLS-2) in the Lubstów deposit (Fig. 4). These deposits are predominantly composed of large-scale horizontally stratified sands with intercalations of silt and very fine gravel. This sedimentary succession additionally contains coaly silts and thin lignite interlayers up to $10 \mathrm{~cm}$ thick (Fig. 4A). Medium- to small-scale trough and ripple cross-stratified sands, forming channel-like structures, are also present. Their bases are erosional in contrast to the flat tops of the chan- 
nels, which are incised within fine-grained clastic deposits (Fig. 4B, C). All these deposits, originally horizontally or subhorizontally stratified, dip towards the east at angles between 48 and $55^{\circ}$, and are faulted. In general, the fault zone and these clastic deposits are high-angle inclined in the same direction, i.e. to the east (Fig. 4).

Normal and reverse faults. The most common tectonic deformation in all lignite opencast quarries examined are normal faults. They are best seen and documented photographically when the lignite seams are layered or interbedded with other sediments or when the fault surfaces are between black lignites and lighter clastic deposits (Fig. 5). These normal faults have a throw from about $2.5 \mathrm{~m}$ to $>6 \mathrm{~m}$. In the case of the two faults shown here, however, their throw observed at a few exploitation levels is between 20 and $50 \mathrm{~m}$ (Fig. 5C, E).

To the same category of normal faults belong deformation structures which consist of a set of two or more parallel or subparallel normal faults occurring at regular intervals. These discontinuities are called step faults, because they have a step-like appearance at both macro- and meso-scale (Fig. 6). Macro-scale step faults are moderately common in the Turów opencast mine. The horizontal distance between the two fault surfaces forming this deformational structure is about 50 to $70 \mathrm{~m}$ (Fig. 6A). Conversely, the meso-scale step faults are characterized by a much more complex structure. For example, the step fault described consists of at least six minor normal faults that are subparallel to the main fault. Generally, all of them dip to the north (Fig. 6B).

Reverse faults have been sporadically documented in the Bełchatów and Lubstów opencast mines (Fig. 7). An exception is here the Turów opencast mine, where this kind of deformation structure is unknown to the present day. The best developed macro-scale reverse faults occur in the Bełchatów opencast mine. Their total throw is probably more than 200 or $300 \mathrm{~m}$ (Widera and Hałuszczak, 2011). However, segments of them are only seen as direct observations in the field (Fig. 7A) By contrast, meso-scale reverse faults have been observed in the Lubstów opencast mine (Widera, 1998, 2007). They have a small throw and low-angle dip to the north-east (Fig. 7B).

Folds, fractures and clastic dikes. Folds are typical of all lignite seams in Poland. Most of them are caused by compaction processes (Kasiński, 2000; Widera, 2013); however, some folds are also tectonically generated (Gotowała and Hałuszczak, 2002; Hałuszczak, 2007). In this study a fold from the Turów opencast mine is analysed (Fig. 8). This fold is composed of layered lignites of SLS-3. Thus, its internal folded structure is also well-expressed (Fig. 8A).

It is characteristic that fractures occur within this fold (Fig. 8B, C). They are almost vertical, perpendicular to the seam top and bedding, and the spacing between them is quite regular, i.e. equal to about $2 \mathrm{~m}$. Moreover, it should be noted that these fractures, seen in plan view on the horizontal exploitation level, are segmented en echelon with the NNW-trending strike (Fig. 8D, E).

Another interesting group of deformation structures that have been identified only in the Bełchatów opencast mine are clastic dikes (Fig. 9). These discontinuities cut the main lignite seam ŚS-3 subvertically, and are predominantly filled with clastic deposits. Occasionally, lignite fragments are also present within the dikes. Their width ranges from a few centimetres to about $12 \mathrm{~m}$, although the distance between them is variable (Fig. 9A). The clastic dikes described form a set of fractures that are subparallel to each other and dip steeply to the north. However, the dip angle increases slightly when moving from the south to the north (Fig. 9B).
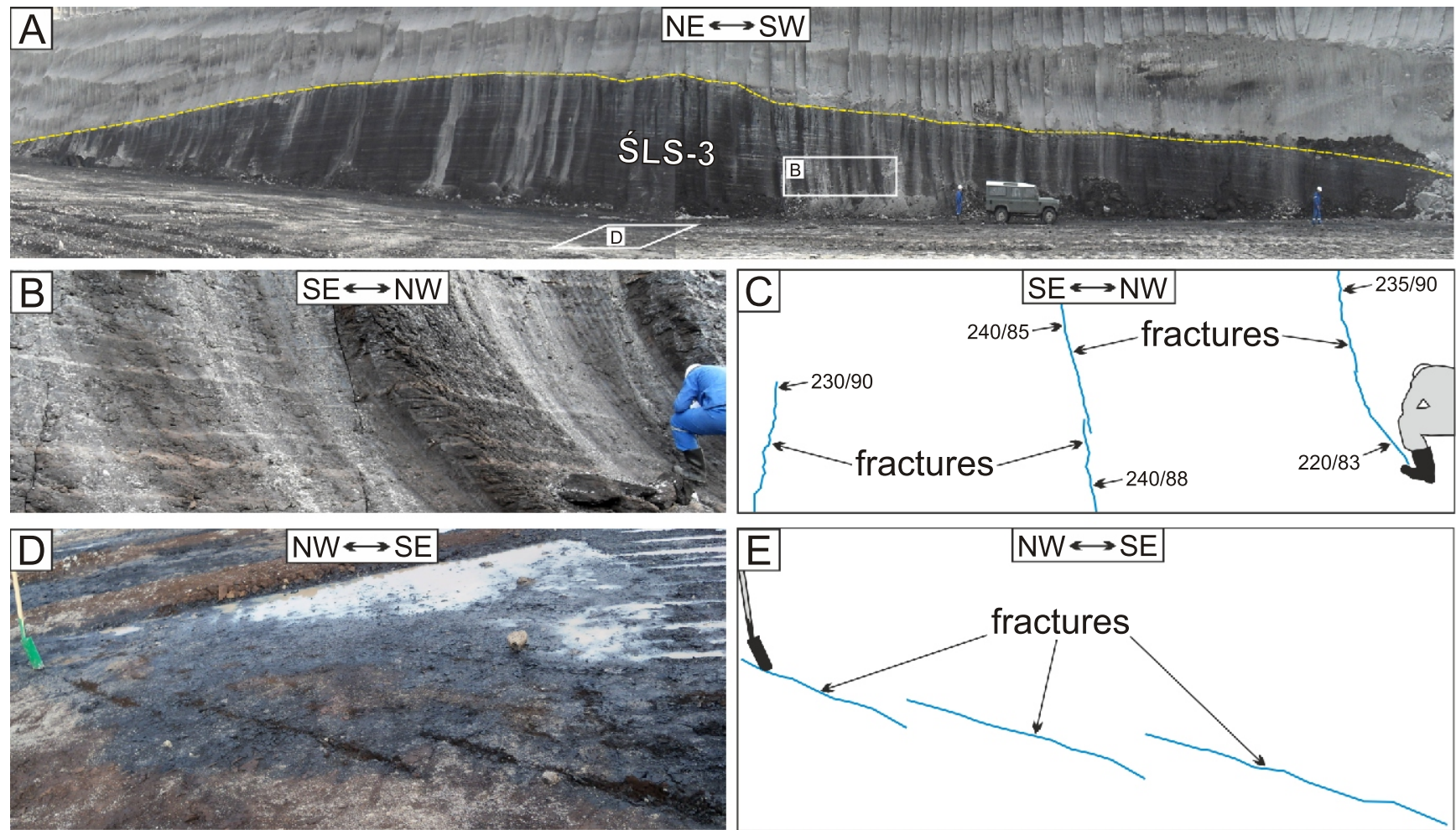

Fig. 8. Tectonically generated fold with fractures in the Turów opencast mine

A - general view of the fold; $\mathbf{B}$ - fractures seen on the vertical wall of the lignite seam; C - interpretative sketch of the photograph shown in Figure 8B; D - fractures seen in plan view; $\mathbf{E}$ - interpretative sketch of the photograph shown in Figure 8D; note the en echelon arrangement of fractures 


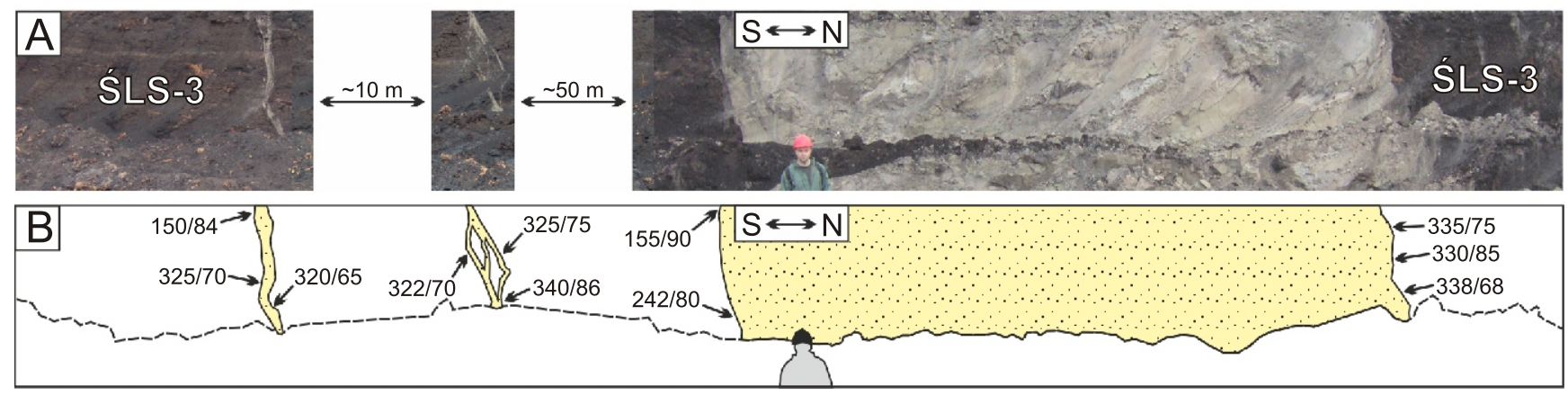

Fig. 9. Clastic dikes cutting ŚLS-3 in the Bełchatów opencast mine

A - general view of the dikes; B - interpretative sketch of the photographs shown in Figure 9A

\section{INTERPRETATION AND DISCUSSION}

In order to interpret the nature of the high-angle inclined deposits their angle of repose must be discussed. These sandy deposits dip at angles of 48 to $55^{\circ}$ (cf. Fig. 4). For dry sands, the angle of repose is usually between 30 and $37^{\circ}$ (Freeman, 2003). The sands under discussion were clearly saturated with water during deposition in flowing conditions. Hence, their original angle of repose must have been at least a few degrees lower, i.e. $<30^{\circ}$, than the values given above. Taking into consideration their origin typical of the distal part of an alluvial fan or a river overbank zone (Widera, 2007), it can be inferred that originally they were stratified horizontally or subhorizontally (Fig. 10A).

During subsidence of the Lubstów Graben the fault (or faults) in the sub-Cenozoic basement was (or were) significantly active, causing the monoclinal tilting of the overlying sandy layers (Fig. 10B). Finally, the angle of repose was exceeded and a new fault zone within the high-angle inclined deposits was created (Fig. 10C). Thus, it can be concluded that the steep inclination of these deposits was generated tectonically from about 18 to $55^{\circ}$. This is estimated as the difference between the currently observed $\left(48\right.$ to $\left.55^{\circ}\right)$ and likely initial (from 0 to $<30^{\circ}$ ) dip angle. An additional argument indicating the tectonic origin of the steep dip of the sandy layers and the fault is the direction of their dip, i.e. to the east (cf. Fig. 4).

The genesis of normal and reverse faults does not require detailed explanation. In general, the normal faults are obviously formed under tension and the reverse faults under compression conditions. The normal and reverse faults are the most commonly occurring tectonic structures in the Polish lignite opencast mines. However, the strike-slip displacement in their development is a very interesting research problem. It is fair to say that, so far, evidence of strike-slip movements have been documented in the Bełchatów opencast mine as lateral displacements, slickensides and striations (Gotowała and Hałuszczak, 2002), and in the Turów opencast mine as the above-mentioned en echelon fractures (cf. Fig. 8D, E). Unfortunately, the precise size of these strike-slip displacements is unknown; however, it is most likely less than the dip-slip displacement described in this study (cf. Figs. 3-5 and 7). Moreover, the above-described step faults look like fragments of flower structures (cf. Fig. 6). These may have formed in transtensional conditions, where only a small component of extension is present (Harding, 1985). An important role of both transtensional and/or transpressional movements in the lignite deformation structures is especially well-expressed in Greek and Turkish opencast mines (e.g., Diamantopoulos et al., 2004; Diamantopoulos, 2006; Yilmaz et al., 2006).

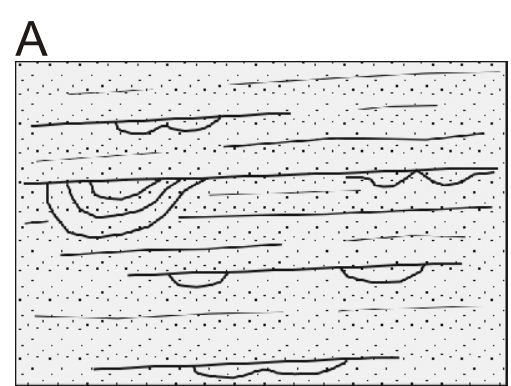

$\mathrm{B}$

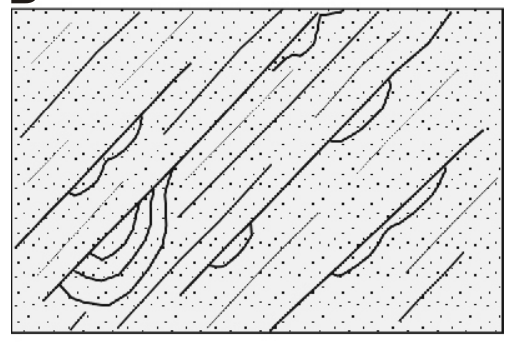

C

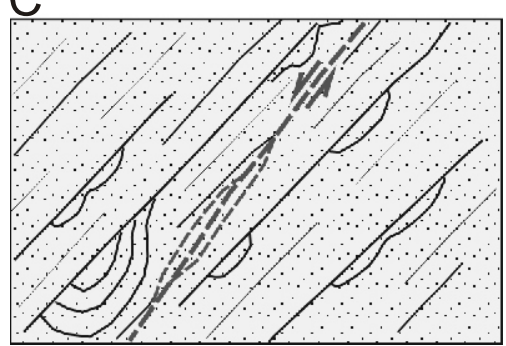

Fig. 10. Conceptual model showing three stages $(\mathrm{A}-\mathrm{C})$ of the formation of the high-angle inclined sandy deposits underlying LLS-2 in the Lubstów opencast mine

Most folds in the lignite seams are of non-tectonic origin. These folds are the result of differential compaction of peat during its transformation into lignite. This is due to both the original and varying thickness of the peat and its composition; for example, mineral matter content, xylite content, and so on (Hager et al., 1981; Widera, 2007, 2013). It occurs when the peat/lignite base is characterized by elevations and depressions. This means that at the time when the peat sedimentation finished its thickness was not even. Then, the syncline in the lignite seam roof was established in places where the seam thickness was 
reduced as a result of uneven compaction (Fig. 11A; Hager et al., 1981). It should be noted here that the process of peat/lignite compaction may have had a very limited impact on fracture formation, including the cleats (Widera, 2014). In the case of the cleats, however, they always consist of two sets of opening-mode fractures that compose a cleat system (Laubach et al., 1998). Conversely, in the case discussed the thickness of the lignite seam is almost the same in various parts of the fold and the fractures form only one set. Thus, the tectonic origin of the fold and fractures must be taken into consideration. It is most likely that the folds were formed by post-depositional tectonic movements. The relative uplift of the horst-like structure in the sub-Cenozoic basement resulted in folding and fracturing of the overlying lignite seam (Fig. 11B). Both the fold and fractures formed in tensional or, as is most likely, in transtensional right-lateral conditions as suggested by the above-mentioned en echelon fractures (cf. Fig. 8D, E).

The final geological problem discussed in this study is the genesis of the clastic dikes from the Bełchatów opencast mine (cf. Fig. 9). In this case, at least two hypotheses should be taken into account. The first hypothesis, proposed by Hałuszczak $(1994,2007)$, suggests the formation of open fractures above the fold axes, which are a result of compression in the Kleszczów Graben. Thus, the dikes must have developed as extensional structures above anticlinal folds of the main lignite seam, SLS-3 and LLS-2. The presence of these structures is limited to the deposits overlying this lignite seam and their age is attributed strictly

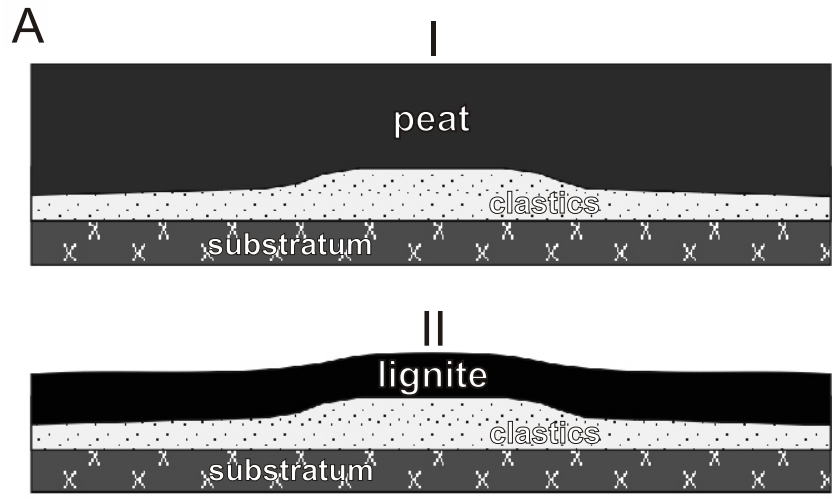

B
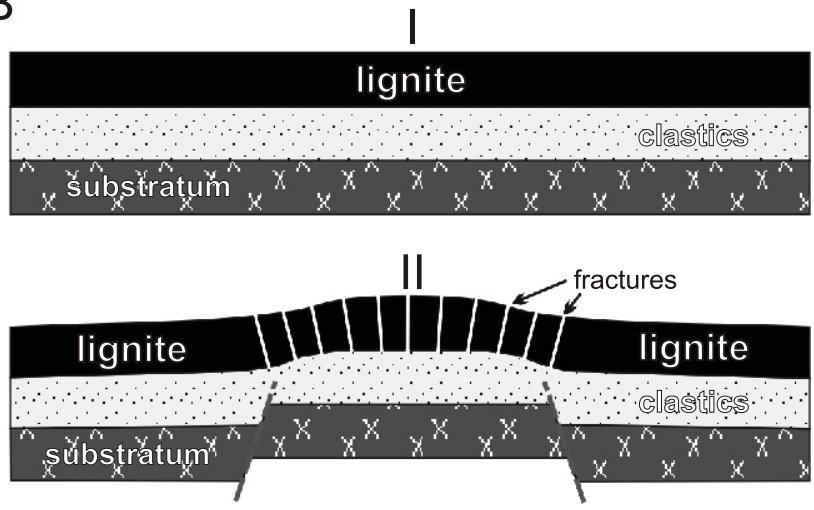

Fig. 11. Conceptual model showing two possible interpretations of the lignite fold and fracture development within ŚS-3 in the Turów opencast mine

A - folding caused by differences in the initial thickness of the peat seam (after Hager et al., 1981, modified); B - folding caused by post-depositional tectonic displacements in the sub-Cenozoic basement of the lignite seam

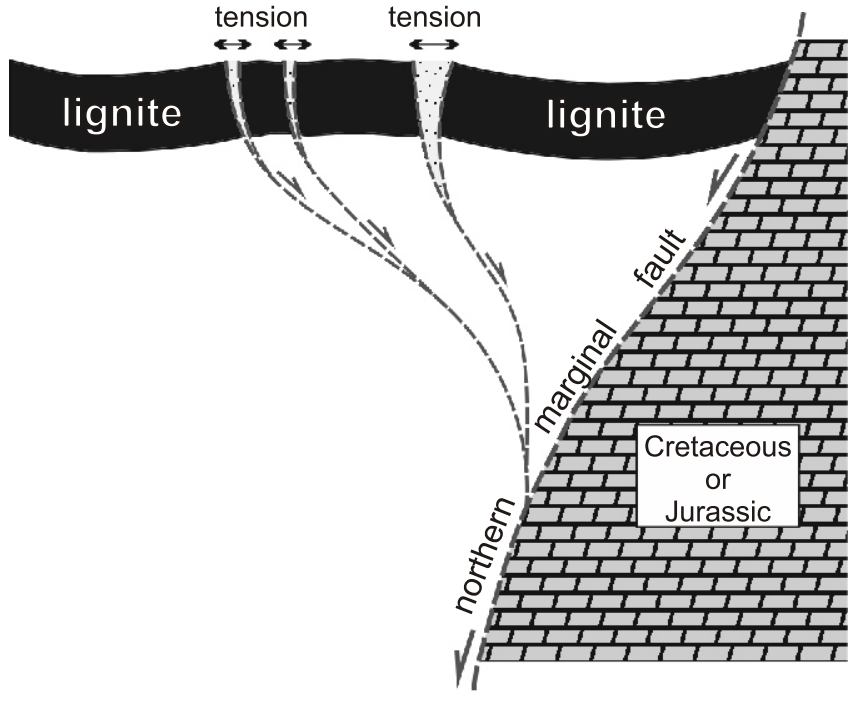

Fig. 12. New conceptual model showing clastic dike development in the Bełchatów opencast mine

to Quaternary tectonics (Hałuszczak, 1994, 2007). In the case of the examples given in this paper, the second hypothesis, which links the dikes' formation with tensional conditions in the graben during the Middle and Late Neogene, can be also taken into consideration. Most likely, both the northern marginal fault and associated secondary faults bordering the dikes, were active tectonically at that time. Together they form the so-called negative flower structure (Fig. 12), which may have formed in transtensional conditions (Harding, 1985). Their genetic relationship is indicated by the similar orientation of these discontinuities, i.e. generally from west to east (cf. Fig. 9). Therefore, at least two different genetic groups of clastic dikes in the Bełchatów opencast mine can be identified. The first group formed in the (trans)compressional and the second in the (trans)tensional stages of the Kleszczów Graben evolution.

\section{CONCLUSIONS}

Tectonic and non-tectonic deformation structures are very common within the lignite seams and associated clastic strata in Polish opencast mines. However, there has been considerable controversy about their origin. Therefore, this study has focused on explaining and discussing their formation.

The Bełchatów, Turów and Lubstów lignite opencast mines, which are sited within relatively deep tectonic grabens, were selected for the field study. The continuous thickness of the Miocene lignite seams is in the range of 35 to over $250 \mathrm{~m}$. The formation of such thick lignites, taking into consideration the peat/lignite compaction, had to result in the creation of a number of tectonic and non-tectonic deformation structures. These structures were divided into three groups in this study. The first group includes high-angle inclined strata. Normal and reverse faults belong to the second group, while the third group consists of folds, fractures and clastic dikes. Although all these structures are broadly of tectonic origin some of them may be the result of processes such as sedimentation or compaction.

Sedimentation processes may in part explain the steeply inclined sand layers, which can create stratification at an angle from 0 to about $30^{\circ}$ in a current. Therefore, sandy layers dipping at angles significantly larger than $30^{\circ}$ needed to be induced by tectonic factors. This inference is supported by the presence of 
normal faults both in these high-angle inclined strata and in their basement. On the other hand, it is more difficult to distinguish the effects of compactional and tectonic processes. These often occur together, but tectonics plays a dominant destructive role. A fold which was tectonically generated is shown in this study. Its tectonic genesis is consistent with its uniform thickness and the presence of extensional fractures within the lignite seam.

Other structures, namely the normal and reverse faults and the clastic dikes, are undoubtedly of tectonic origin. The challenge for the future is to attempt to reconstruct in detail the mechanisms and the time of their formation. Therefore, it is suggested that further research should be aimed primarily at determining more precisely the role of strike-slip movements in the creation of both the macro- and meso-scale deformation structures as well as the grabens, which are filled with the thickest Polish lignite deposits.
Acknowledgements. The author wishes to thank the Polish lignite companies for permission to conduct fieldwork in their opencast mines. Sincere gratitude is due to the staff of the Geology Departments from these mines, while E. Dąbrowska, M. Szkudlarek and Z. Marek from the Turów Lignite Mine are especially thanked for their hospitality and help in the field. The following of my students: K. Berendt, G. Grześkowiak, R. Szarzyński, A. Szewczyk and D. Wiktorski are warmly thanked for their field assistance and the pleasant working atmosphere they created. P. Selvakumaran (Process \& Captive Power Systems, Bharat Heavy Electricals Ltd., Tiruchirappalli, India) and J.R. Kasiński (Polish Geological Institute, Warsaw, Poland) are acknowledged for valuable comments and suggestions that improved the quality of this paper. The Editor-in-Chief of the Geological Quarterly, T.M. Peryt, is kindly thanked for his editorial help.

\section{REFERENCES}

Ciuk, E., Piwocki, M., 1990. Map of brown-coal deposits and prospect areas in Poland, scale 1:500,000. Państwowy Instytut Geologiczny, Warszawa.

Czarnecki, L., Frankowski, R., Kuszneruk, J., 1992. Syntetyczny profil litostratygraficzny utworów trzeciorzędu złoża Bełchatów. In: Sympozium: "Geologia formacji węglonośnych Polski” (ed. I. Lipiarski): 15. Wydawnictwo Akademii Górniczo-Hutniczej, Kraków.

Diamantopoulos, A., 2006. Plio-Quaternary geometry and kinematics of Ptolemais Basin (Northern Greece): implications for the intra-plate tectonics in Western Macedonia. Geologia Croatica, 59: 85-96.

Diamantopoulos, A., Dimitrakopoulos, D., Fountoulis, I., 2004. Quaternary deformation of the Mavropigi Lignite Field (western margin of Ptolemais-Kozani Graben, NW Macedonia, Greece). Bulletin of the Geological Society of Greece, 36: 310-319.

Freeman, T., 2003. Environmental Geology Laboratory. Wiley, New York.

Gotowała, R., Hałuszczak, A., 2002. The Late Alpinie structural development of the Kleszczów Graben (Central Poland) as a result of a reactivation of the pre-existing, regional dislocation. EGU Stephan Mueller Special Publication Series, 1: 137-150.

Grimm, K., Grimm, M., Huss, M., Jansen, F., Prüfert, A., Gürs, K., Lietzow, A., Ritzkowski, S., Standke, G., Blumenstengel, H., Bülow, W., Hottenrot, M., Doppler, G., Heissig, K., Reichenbacher, B., Schwerd, K., 2002. Tertiary. In: German Stratigraphic Commission (ed.). Stratigraphic Table of Germany 2002.

Hager, H., Kothen, H., Spann, R., 1981. Zur Setzung der Rheinischen Braunkohle und ihrer klastischen Begleitschichten. Fortschritte in der Geologie von Rheinland und Westfalen, 29: 319-352.

Harding, T.P., 1985. Seismic characteristics and identification of negative flower structure, positive flower structures and structural inversion. AAPG Bulletin, 69: 17-39.

Hałuszczak, A., 1994. Clastic dikes in uppermost Tertiary sediments of the Kleszczów Graben and their significance to reconstruction of Quaternary diastrophism. Geological Quarterly, 38 (1): 117-132.

Hałuszczak, A., 2004. Cenozoic dynamics of the Dębina Salt Dome, Kleszczów Graben, inferred from structural features of the Tertiary-Quaternary cover. Annales Societatis Geologorum Poloniae, 74: 311-318.
Hałuszczak, A., 2007. Dike-filled extensional structures in Cenozoic deposits of the Kleszczów Graben (Central Poland). Sedimentary Geology, 193: 81-92.

Jarosiński, M., Poprawa, P., Ziegler, P.A., 2009. Cenozoic dynamic evolution of the Polish Platform. Geological Quarterly, $\mathbf{5 3}$ (1): $3-26$.

Kasiński, J.R., 2000. Geological atlas of the Tertiary lignite-bearing association in the Polish part of the Zittau Basin, scale 1:50,000 (in Polish and English). Państwowy Instytut Geologiczny, Warszawa.

Kasiński, J.R., Czapowski, G., Piwocki, M., 2009. Halokinetic impact on origin of the Tertiary lignite deposits on the Polish Lowlands (in Polish with English summary). Przegląd Geologiczny, 57: 964-975.

Kasiński, J.R., Badura, J., Pańczyk, M., Pécskay, Z., Saternus, A., Słodkowska, B., Urbański, P., 2015. Paleogene deposits in the Polish part of the Zittau Basin - new light on the age of the tectonic depression (in Polish with English summary). Biuletyn Państwowego Instytutu Geologicznego, 461: 193-250.

Laubach, S.E., Marrett, R.A., Olson, J.E., Scott, A.R., 1998. Characteristics and origins of coal cleat: a review. International Journal of Coal Geology, 35: 175-207.

Malkovsky, M., 1987. The Mesozoic and Tertiary basins of the Bohemian Massif and their evolution. Tectonophysics, 137: 31-42.

Piwocki, M., 1992. Extent and correlations of main groups of the Tertiary lignite seams on Polish platform area (in Polish with English summary). Przegląd Geologiczny, 40: 281-286.

Piwocki, M., Kasiński, J.R., 1994. Map of the economic and ecological evaluation of lignite deposits in Poland, scale 1:750,000. Państwowy Instytut Geologiczny, Warszawa.

Piwocki, M., Ziembińska-Tworzydło, M., 1997. Neogene of the Polish Lowlands - lithostratigraphy and pollen-spore zones. Geological Quarterly, 41 (1) 21-40.

Rajchl, M., Uličný, D., Grygar, R., Mach, K., 2009. Evolution of basin architecture in an incipient continental rift: the Cenozoic Most Basin, Eger Graben (Central Europe). Basin Research, 21: 269-294.

Špičáková, L., Uličný, D., Koudelková, G., 2000. Tectonosedimentary evolution of the Cheb Basin (NW Bohemia, Czech Republic) between Late Oligocene and Pliocene: a preliminary note. Studia Geophysica et Geodaetica, 44: 556-580.

Standke, G., Rascher, J., Strauss, C., 1993. Relative sea-level fluctuations and brown coal formations around the Early-Middle 
Miocene boundary in the Lusatian Brown Coal District. Geologische Rundschau, 82: 295-305.

Vinken, R. (compiler), 1988. The Northwest European Tertiary basin, results of the IGCP. Project No. 124. Geologisches Jahrbuch, A100.

Widera, M., 1998. Palaeomorphological and palaeotectonical evolution of the Konin Elevation (in Polish with English summary). Geologos, 3: 55-103.

Widera, M., 2007. Lithostratigraphy and palaeotectonics of the sub-Pleistocene Cenozoic of Wielkopolska (in Polish with English summary). Adam Mickiewicz University Press, Poznań.

Widera, M., 2011. Postsedimentary tectonic uplift in the Lubstów Graben (in Polish with English summary). Przegląd Geologiczny, 59: 681-687.

Widera, M., 2013. Changes of the lignite seam architecture - a case study from Polish lignite deposits. International Journal of Coal Geology, 114: 60-73.
Widera, M., 2014. Lignite cleat studies from the first Middle-Polish (first Lusatian) lignite seam in central Poland. International Journal of Coal Geology, 131: 227-238.

Widera, M., Hałuszczak, A., 2011. Stages of the Cenozoic tectonics in central Poland: examples from selected grabens. Zeitschrift der Deutschen Gesellschaft für Geowissenschaften, 162: 203-214.

Widera, M., Kita, A., 2007. Paleogene marginal marine sedimentation in central-western Poland. Geological Quarterly, 51 (1): 79-90.

Yilmaz, H., Over, S., Ozden, S., 2006. Kinematics of the East Anatolian Fault Zone between Turkoglu (Kahramanmaras) and Celikhan (Adiyaman), eastern Turkey. Earth Planets Space, 58: 1463-1473.

Ziegler, P.A., Dèzes, P., 2007. Cenozoic uplift of Variscan massifs in the Alpine foreland: Timing and controlling mechanisms. Global and Planetary Change, 58: 237-269. 